\title{
Funding Solar Projects at Federal Agencies: Mechanisms and Selection Criteria
}

\section{Introduction}

Implementing solar energy projects at federal facilities is a process. The project planning phase of the process includes determining goals, building a team, determining site feasibility, and selecting the appropriate project funding tool. This document gives practical guidance to assist decision-makers with selecting the funding tool that would best meet their site goals. Because project funding tools are complex, federal agencies should seek project assistance before making final decisions.

High capital requirements combined with limits on federal agency energy contracts create challenges for funding solar projects. Solar developers typically require long-term contracts (15-20) years to spread out the initial investment and to enable payments similar to conventional utility bill payments. In the private sector, 20 -year contracts have been developed, vetted, and accepted, but the General Services Administration (GSA) contract authority (federal acquisition regulation [FAR] part 41) typically limits contract terms to 10 years. Payments on shorter-term contracts make solar economically unattractive compared with conventional generation. However, in several instances, the federal sector has utilized innovative funding tools that allow long-term contracts or has created a project package that is economically attractive within a shorter contract term.

\section{Part I: Selecting a Project Funding Tool}

The following sections outline five funding tools that federal agencies have used to implement solar projects. Each section includes a short description, advantages and challenges, and rules of thumb to judge the appropriateness of the funding tool. There are many exceptions to the rules of thumb listed, and a project could be implemented through one funding tool or a combination of them. Agencies also have access to free assistance through the U.S. Department of Energy's (DOE) Federal Energy Management Program (FEMP) financing specialists. ${ }^{1}$ It is also good practice to gauge developer interest before moving to implement a funding tool.

\section{Agency-Funded Project}

Agency-funded or agency-appropriated projects have money designated for the outright purchase of a solar energy system. The government owns the system, its energy production, and all the environmental attributes produced (e.g., solar renewable energy credits [SRECs] and clean energy credits [CECs]).

\footnotetext{
${ }^{1}$ The contact information for the federal financing specialists can be found on the FEMP website at: wwwl.eere.energy.gov/femp/financing/espcs_financingspecialists.html.
} 
- Well-understood project funding tool

- Similar to many federal capital projects

- Incurs no financing costs

- Stable long-term energy prices
- Agency is responsible for operations and maintenance $(\mathrm{O} \& M)$ arrangements (including inverter replacement) but can purchase an O\&M service contract

- No assurance of long-term performance (can purchase optional long-term performance guarantees, which differ from a manufacturer's warranty)

- Cannot monetize available tax incentives

- Appropriations may not be readily available for the project

If the agency has budgeted funding for a solar project that meets its goals, then purchasing a system could be the preferred option as it tends to lower internal transaction costs and is likely to have a lower overall cost to the taxpayer. However, an agency-funded project may not produce the best project-level economics as tax benefits cannot be utilized.

\section{Agency-Funded Project Examples²}

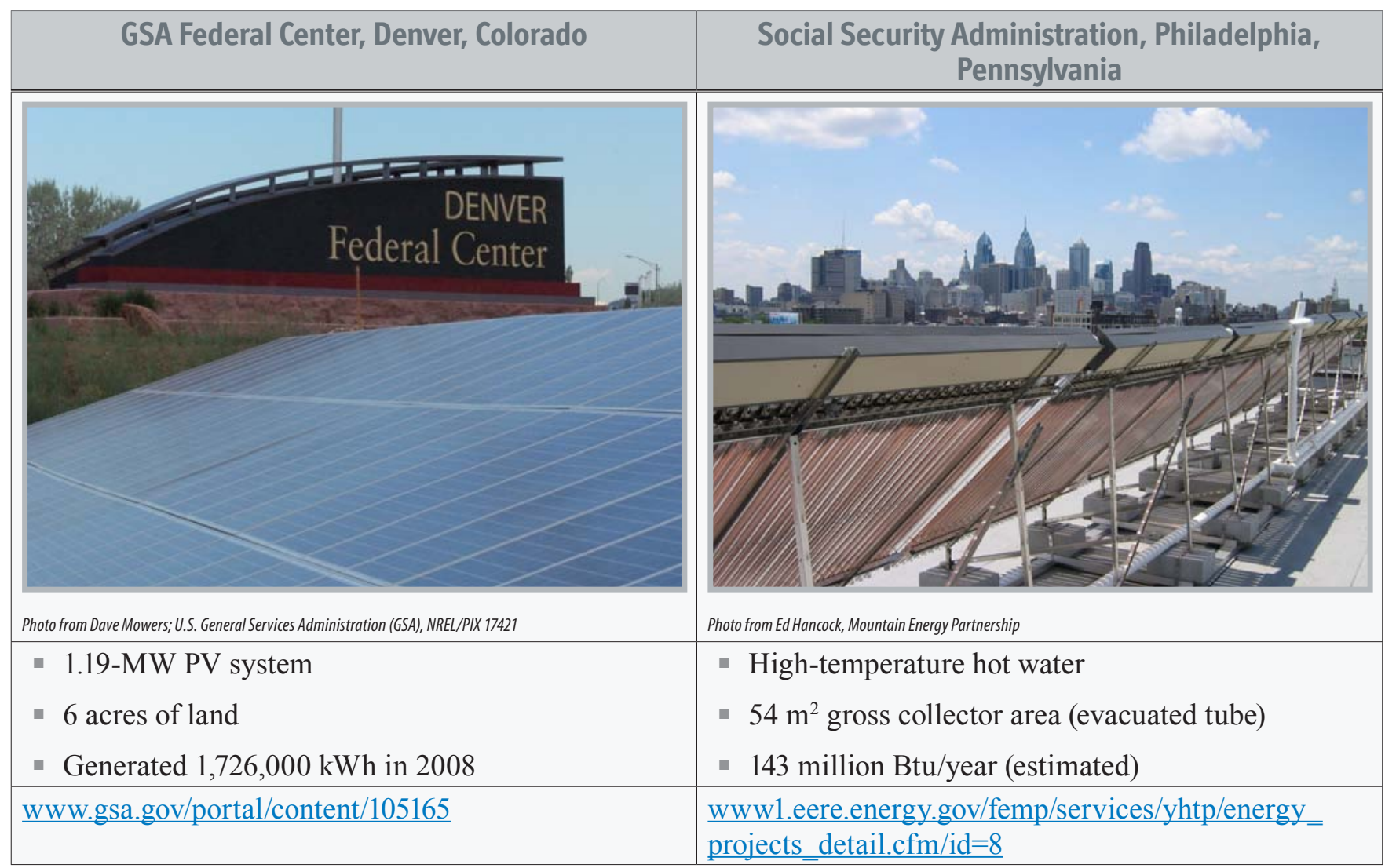

\footnotetext{
${ }^{2}$ System details were included to the extent information was available, and therefore not all examples have equivalent data points.
} 


\section{Federal On-Site Renewable Power Purchase Agreement}

Federal on-site renewable power purchase agreements (PPAs) are contracts for energy. On-site PPAs have been used to finance solar projects in the private sector since 2003 and are now commonly used for commercial installations. Under an on-site renewable PPA, a private entity installs, owns, operates, and maintains the customer-sited, solar energy generation system. The federal facility purchases electricity or thermal energy through a long-term contract with specified prices. Payment is based on actual energy (kilowatt-hours or MMBtu) generated from the solar equipment and consumed by the site. On-site renewable PPAs are more common for solar electric than solar thermal installations, but they can be used for either system type. ${ }^{3}$ FEMP offers more details in its PPA Quick Guide: www.nrel.gov/docs/fyllosti/51662.pdf.

Advantages

- Private developers may be eligible for tax incentives, RECs, and accelerated depreciation, and these savings can be passed along to the agency in the form of a lower electricity rate

- Agency is typically not required to provide upfront capital

- Renewable energy system owner provides O\&M for the duration of the contract

- Government only pays for energy delivered

- Agency typically receives a known long-term electricity or thermal energy price for a portion of the site load, reducing the price risk of fluctuating utility energy prices

- Developer has incentive to maximize system production because energy payment is based on actual production

- Without constraints of appropriated funding or required savings, PPAs can enable a system size that best meets site goals

\section{Challenges}

- Transaction costs may include a significant learning curve and time investment

- Federal-sector experience is limited both in terms of agencies and developers capable of executing due to sector-specific challenges

- Civilian agencies are limited to a maximum10year term for PPA contracts; however, the U.S. Department of Defense (DOD) is permitted up to 30-year terms under 10 USC 2922a

- Possible contracting issues due to federal regulations include termination for convenience, land-use agreements, and assignment and novation

- To secure needed financing, developers usually require solar PV projects to be at least $500 \mathrm{~kW}$ in size (solar thermal thresholds are unknown because of a lack of projects); smaller solar PV systems are sometimes acceptable and could be aggregated to achieve minimum scale

- Some states do not allow third-party PPAs

An on-site renewable PPA may warrant further investigation if:

- There is not enough funding to cover the upfront cost of the project

- The size of the project is greater than $500 \mathrm{~kW}$

- The state in which the project is located does not apparently disallow PPAs (check www.dsireusa.org/documents/ summarymaps/3rd_Party_PPA_map.ppt)

- The project is for the DOD and the 10 USC 2922a 30-year contract authority is an option

- The project is in Western Area Power Administration's (Western) territory; Western has long-term contract authority and can act as contractual intermediary for federal agencies. The Western service territory map can be accessed at: www.wapa.gov/crsp/customerscrsp/pdf/region2.pdf.

\footnotetext{
${ }^{3}$ Also, solar thermal PPAs may not have as many barriers to overcome as solar electric projects (e.g., barriers against independent power producers in electricity generation).
} 
As noted above, making an on-site renewable PPA economically attractive usually requires a long-term contract. Without specific long-term contract authority, PPAs need to be creatively designed to meet economic thresholds. Innovative options have included:

- Using Western as a contractual intermediary with long-term contract authority, as was done at the U.S. Department of Energy's National Renewable Energy Laboratory and Fort Carson. Western does not work under the FAR construct, and therefore it does not need to meet those requirements. Sites must be in Western territory to use this option. Other federal power administrations may have this contracting authority, but no projects have been completed at the time of this writing.

- Making a large PPA payment in the first year and using a typical 10-year contract. In this case the agency must have sufficient funds in the first year and confirm form of payment is within agency's authority.

The following two additional models were customized for the specific circumstances of the project:

- Providing the project owner a long-term land-use agreement of more than 20 years combined with a short-term PPA contract of less than 10 years with options to renew. Depending on the project circumstances, this could increase the risk to the developer and may increase the cost (i.e., higher risk leads to higher targeted returns by developers as well as their financiers).

- Providing the project owner a long-term land-use agreement combined with an indefinite-term PPA contract with a 1-year termination option (e.g., Nellis Air Force Base, Nevada- www.3phases.com/news/news-item.php?id=34 ). This option increases risk to the developer and would therefore require mitigating economic factors, such as attractive long-term REC prices.

Site-specific examination is recommended to ensure the circumstances that allowed these projects to be financed are replicable.

\section{On-Site Renewable PPA Examples}

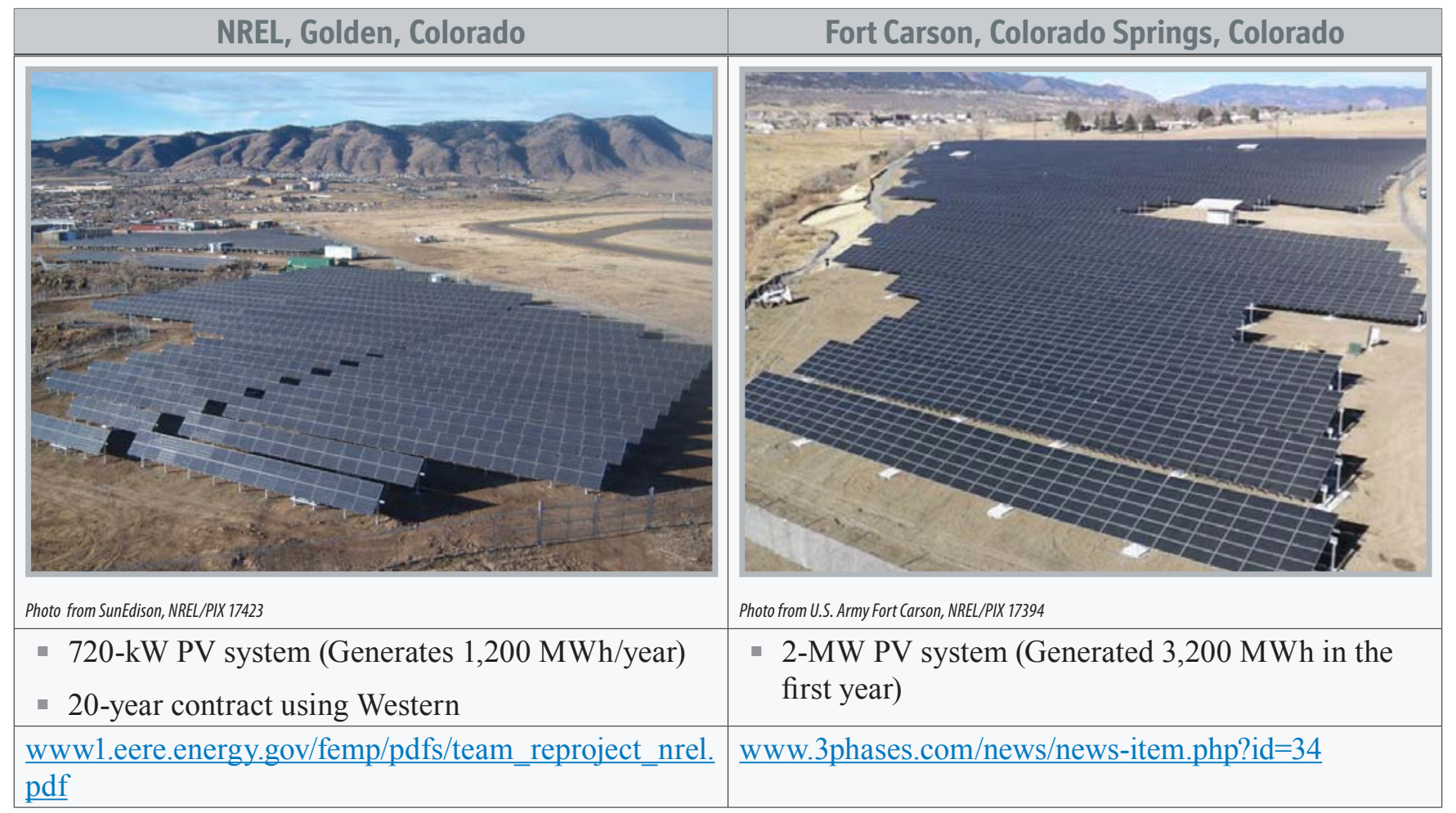




\section{Energy Savings Performance Contract}

Energy savings performance contracts (ESPCs) have a long history of use in the federal sector and have primarily been used for energy efficiency projects. ESPCs are increasingly seen, however, as a long-term financing method for solar projects. ESPC efficiency improvements combined with solar can make an economically viable bundled package. An ESPC is a guaranteed savings contracting mechanism that requires no upfront capital funding. An energy services company (ESCO) incurs the cost of implementing a range of energy conservation measures - which can include solarand is paid from the energy, water, and operations savings that result (DOE EERE 2010). The ESCO and the agency determine who operates and maintains the conservation measures. Payments to the contractor cannot exceed savings in any given year. These contracts are generally recommended for renewable energy projects only if combined with energyefficiency measures.

Federal agencies may pursue ESPCs via two paths:

- An indefinite-delivery, indefinite-quantity (IDIQ) master contract; at least two IDIQ options are available to the federal sector. The DOE IDIQ ESPC enables federal agencies to work with 16 prequalified ESCOs for projects at any federally owned facility worldwide. The Army also offers an IDIQ ESPC.

- A "site-specific" ESPC uses a traditional request for proposal (RFP) methodology but borrows the format and many of the terms and conditions of DOE's IDIQ contract. This option could potentially be used to contract directly with a solar developer, but as of this writing, there are no examples.

\begin{tabular}{|c|c|}
\hline Advantages & Challenges \\
\hline $\begin{array}{l}\text { The } 25 \text {-year maximum contract authority fits } \\
\text { well with longer renewable energy project } \\
\text { paybacks } \\
\text { - The annual energy production (kWh/yr or } \\
\text { MMBtu/yr) is counted as savings and is part of } \\
\text { the guaranteed savings package } \\
\text { - O\&M can be included as part of the contract } \\
\text { - The agency in charge of the site can require that } \\
\text { solar be a part of the project } \\
\text { - A project facilitator is assigned and funded by } \\
\text { FEMP through an initial proposal or preliminary } \\
\text { assessment }\end{array}$ & $\begin{array}{l}\text { Because ESCOs traditionally do not own assets, } \\
\text { an additional agreement to allow third-party } \\
\text { ownership of the system is required to monetize } \\
\text { tax incentives related to solar } \\
\text { - Because of ESPC annual payment limitations, it } \\
\text { can be difficult to make solar-only projects work, } \\
\text { especially without tax incentives } \\
\text { - Can involve a large contracting transaction, } \\
\text { resulting in significant project management costs } \\
\text { and/or lengthy processes } \\
\text { In most cases, renewable projects alone do not } \\
\text { provide sufficient savings to justify an ESPC and } \\
\text { must be done along with efficiency projects to } \\
\text { balance the cost } \\
\text { - Guarantees are only as strong as the measure- } \\
\text { ment and verification options and their associated } \\
\text { methodologies } \\
\text { Limited to smaller-size projects because of the } \\
\text { need to bundle with non-renewable projects }\end{array}$ \\
\hline
\end{tabular}

The DOE IDIQ ESPC should be considered if:

- There is not enough appropriated funding to pay for the project up front

- Energy efficiency upgrades in addition to solar are being considered

- The typical solar system size is under $1 \mathrm{MW}$ (maximum size is dependent upon capturing incentives and/or available savings from bundled energy efficiency upgrades) 
As with PPAs, longer-term contracts are generally required to make ESPCs economically viable. The DOE IDIQ ESPC has a 25 -year contract authority, which enhances financial viability. The U.S. Coast Guard has also been successful in making one of the ESPC's energy conservation measures a PPA for solar (formerly known as an energy services agreement or ESA) to allow third-party ownership and improve project economics within the DOE IDIQ ESPC (http:// coastguard.dodlive.mil/2011/06/reduce-reuse-recycle-aguadilla-puerto-rico/).

The site-specific ESPC should be considered if:

- There is not enough appropriated funding to the pay for the project upfront

- The project is solar-only, not combined with efficiency measures

- The system size is relatively large (e.g., greater than $1 \mathrm{MW}$ )

A site-specific ESPC may be used to contract directly with a solar developer. Developers have shown interest, but at this time, there are no examples. The advantage of this type of ESPC is that it can lower system costs, but it will likely still require the additional time and expense of a competitive RFP process.

As with all ESPCs, the annual payments to the company supplying the energy cannot exceed the annual energy savings. In other words, for solar-only ESPCs, the estimated cost per kWh or Btu produced by the solar system needs to be the same or lower than what the site spends on energy from present sources. In a combined solar and energy efficiency project, the energy efficiency savings can help "subsidize" solar energy that is often more expensive than utility power, such that the bundled project meets the annual cost-savings requirement. Larger systems that benefit from economies of scale and high utility rates help make ESPCs work for solar-only projects. Also, agencies that have the authority to sell government property and retain the proceeds, rather than returning them to the U.S. Treasury, can sell renewable energy credits or carbon credits to improve the economics of the project. One agency that has done this is the GSA.

\section{ESPC Examples}

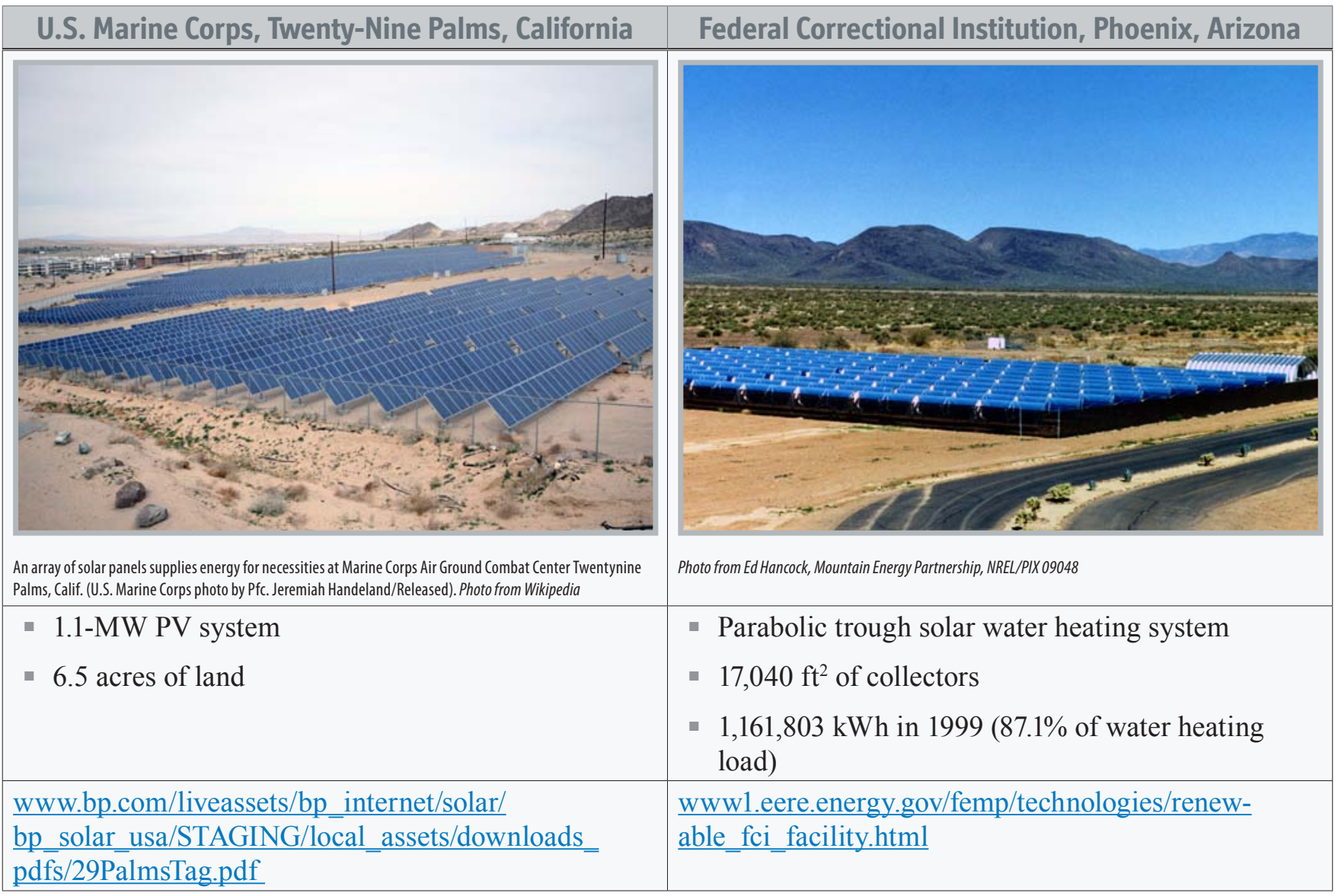




\section{Utility Energy Services Contract}

Utility energy services contracts (UESC), like ESPCs, have a history of use in the federal sector primarily for energy efficiency projects. Now, these contracts are also being seen as a method of long-term financing for solar projects. A UESC is an agreement that allows a serving utility to provide an agency with comprehensive energy- and water-efficiency improvements and demand-reduction services. The utility could partner with an ESCO to provide the installation, but the utility remains the prime contractor. Depending on project payback, a UESC could be used for a renewable-only project but, like an ESPC, renewable projects will typically be bundled with efficiency measures. The steps in the UESC process are similar to other contracting mechanisms and include identifying opportunities, completing a detailed analysis, negotiating the contract, completing construction, testing performance, accepting the project, and handling any postacceptance issues.

\section{Advantages}

- The UESC contract term limit is not legislated and varies by agency with a maximum of 25 years

- The GSA legal opinion states that agencies may enter into utility agreements with a timeframe greater than 10 years

- Investor-owned utilities are eligible for a renewable investment tax credit (the utility must own the renewable energy plant); the agency can indirectly benefit from the tax savings

- Interconnection, tariff, and standby issues (e.g., capacity charge) are often minimal with utility ownership (not always true and should be explored prior to proceeding)

- Utilities are interested in a wide range of project sizes in comparison to the PPA model, which are typically used for larger systems (e.g., $500 \mathrm{~kW}$ or larger) on federal sites

- A relationship between the utility and the federal agency already exists

- Utilities often have access to favorable financing rates due to their financial strength

- Utilities subject to renewable energy mandates want to add eligible energy to their mix

\section{Challenges}

- Not all utilities offer UESCs, though FEMP is helping launch UESC programs

- Utilities may be resistant to participating in a UESC due to concern about adding renewable power to their grid (FEMP technical assistance can help)

- Concerns often arise for some agencies regarding contract terms longer than 10 years

Several different contracting mechanisms are available for implementing a UESC:

- GSA area-wide contract (AWC)

- Separate Contract (used in absence of GSA AWC)

- Basic Ordering Agreement (BOA)

- Master Agreement (used underneath an AWC or as a stand-alone contract) 
An agency can use any of these approaches; however, when an AWC exists, FAR states that agencies should use it to acquire service except under extraordinary circumstances. The GSA has developed AWCs with more than 100 utilities for use by all agencies within a participating utility's service area. A list of available AWCs can be found at: www.gsa.gov/ portal/content/104187. To acquire service, agencies place a delivery order under the specific AWC.

When an AWC does not exist and an agency intends to implement many task orders, a BOA or Master Agreement can be used. BOAs are general terms and conditions for future contracts and are negotiated between an agency and a utility. A BOA may be specific to one agency or it may allow use by others. A UESC model agreement has been developed through a multi-agency collaborative effort and can be used as the basis of a separate contract for utility energy management services, a master agreement, or a BOA. UESC projects may be implemented with appropriated dollars, private financing, or any combination of the two. ${ }^{4,5}$

A UESC should be considered if:

- There is insufficient funding to pay for the project up front

- A serving utility offers energy and demand-side management services or is willing to offer a UESC

- Energy efficiency upgrades are also considered ${ }^{6}$

- System size is under $1 \mathrm{MW}$

If contemplating a larger solar electric-only system (e.g., greater than $1 \mathrm{MW}$ ), another option is a utility renewable electricity service contract (URESC). Under this type of agreement the utility provides power to the agency from an on-site solar electric system. The utility can either own the solar system or purchase the power from a third-party owner. URESCs are being used for multiple projects that are several megawatts apiece.

\section{UESC Examples}

\begin{tabular}{|l|l|}
\hline Camp Pendleton, North San Diego County, California & Joshua Tree National Park, California \\
\hline &
\end{tabular}

\footnotetext{
4 The FEMP UESC model agreement as well as other resources can be found here: wwwl.eere.energy.gov/femp/financing/uescs types.html\#ma. All three types of UESC contracting typically rely on the utility incentive authority of 42 USC 8256.

6 There is an unresolved question of the regulatory requirement for utilities to normalize the tax credit, thus reducing its economic effectiveness. For more information on utility tax normalization, see: http://financere.nrel.gov/finance/content/normal-accounting-rules-limit-utility-ownership-renewable-energy-projects.
} 


\section{Enhanced Use Lease}

An enhanced use lease (EUL) is a real estate transaction that derives income from underutilized but non-excess land. Prospective developers compete for the lease, and payment can be either monetary or an in-kind consideration (e.g., solar generated electricity). The value of the lease is used to determine the amount of the consideration. An EUL typically is used for large projects (e.g., greater than $1 \mathrm{MW}$ and possibly greater than the site load).

\begin{tabular}{|c|c|}
\hline Advantages & Challenges \\
\hline $\begin{array}{l}\text { Monetizes potential value of underutilized } \\
\text { property (can be a stand-alone lease with no } \\
\text { energy sold or remunerated back to the host } \\
\text { agency) } \\
\text { - Supplements underfunded facilities' costs }\end{array}$ & $\begin{array}{l}\text { Currently only DOD, National Aeronautics and } \\
\text { Space Administration (NASA), and the U.S. } \\
\text { Department of Veterans Affairs (VA) have the } \\
\text { authority to execute an EUL } \\
\text { " Must not be excess property as defined by } 40 \\
\text { U.S.C. } \$ 102 \\
\text { - Market value of lease may be difficult to } \\
\text { determine if property does not have comparables } \\
\text { (e.g., land is remote or contains environmental } \\
\text { hazards) } \\
\text { - Can be extremely time consuming to execute } \\
\text { - Land used by DOD that is BLM withdrawn } \\
\text { land can only be used for military purposes. } \\
\text { Renewable energy generation on withdrawn land } \\
\text { in excess of that needed for military purpose } \\
\text { triggers development under the BLM right of } \\
\text { way process. }\end{array}$ \\
\hline
\end{tabular}

An EUL should be considered if:

- There is insufficient funding for the project

- DOD, NASA, or the VA is leading the project $^{7}$

- The proposed system is greater than $1 \mathrm{MW}$

- The land is "underutilized" but not "excess" and wholly owned, leased, or licensed by the agency for at least the length of the contract

EULs typically are more complex and have high transaction costs; therefore, they have only been used for larger installations. Large projects may produce more energy than the site can absorb and require a market in close proximity, such as a utility, to purchase the excess energy. Larger systems can help to maximize the value of the project to the agency. 


\section{EUL Examples}

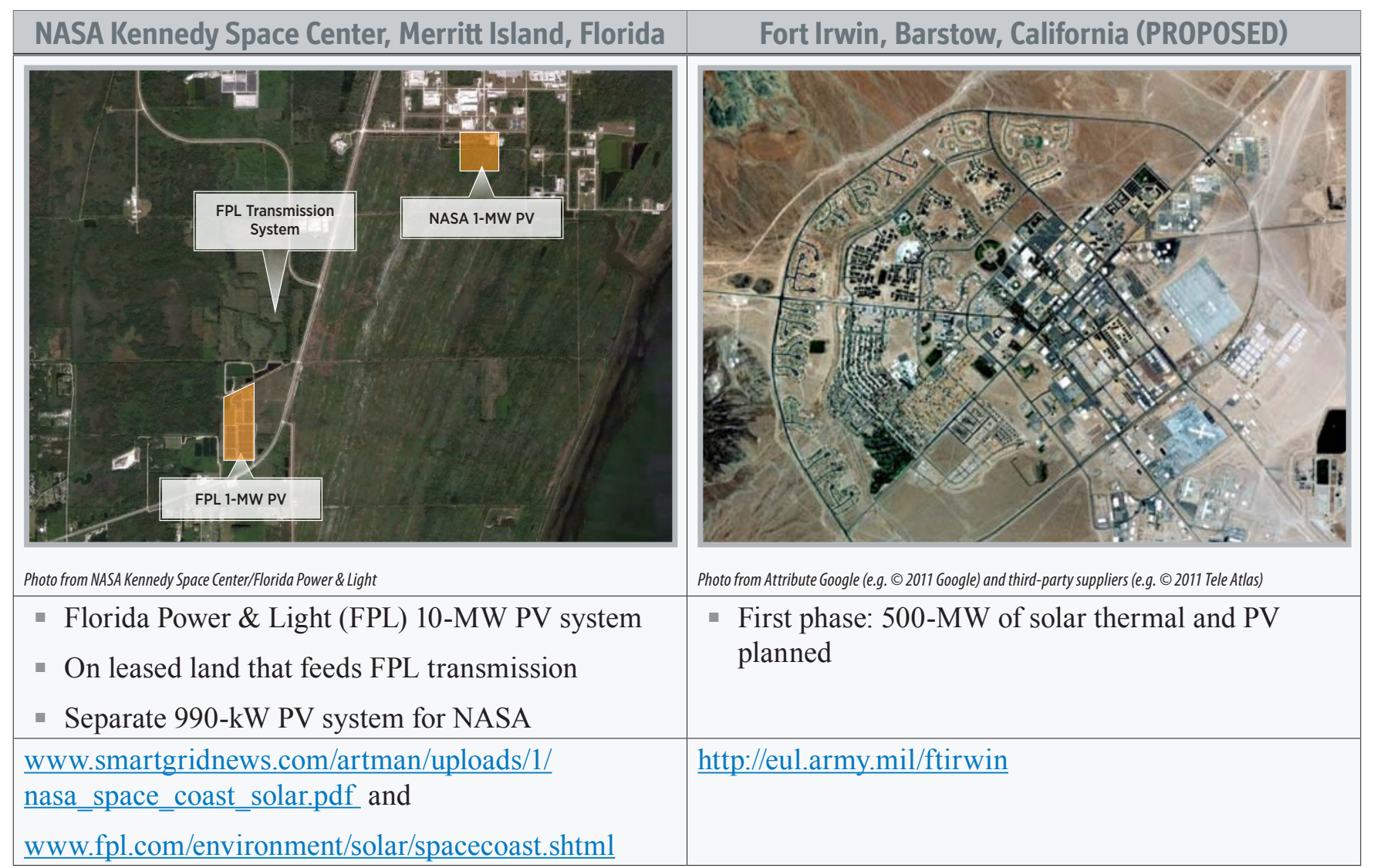




\section{Part II: Implementing Project Funding Tools}

Each funding tool has its own implementation pathway. Some implementation processes are more rigid than others, but there are variations on the steps. Figure 1 illustrates recommended steps in the processes that are outlined for each of the funding tools.

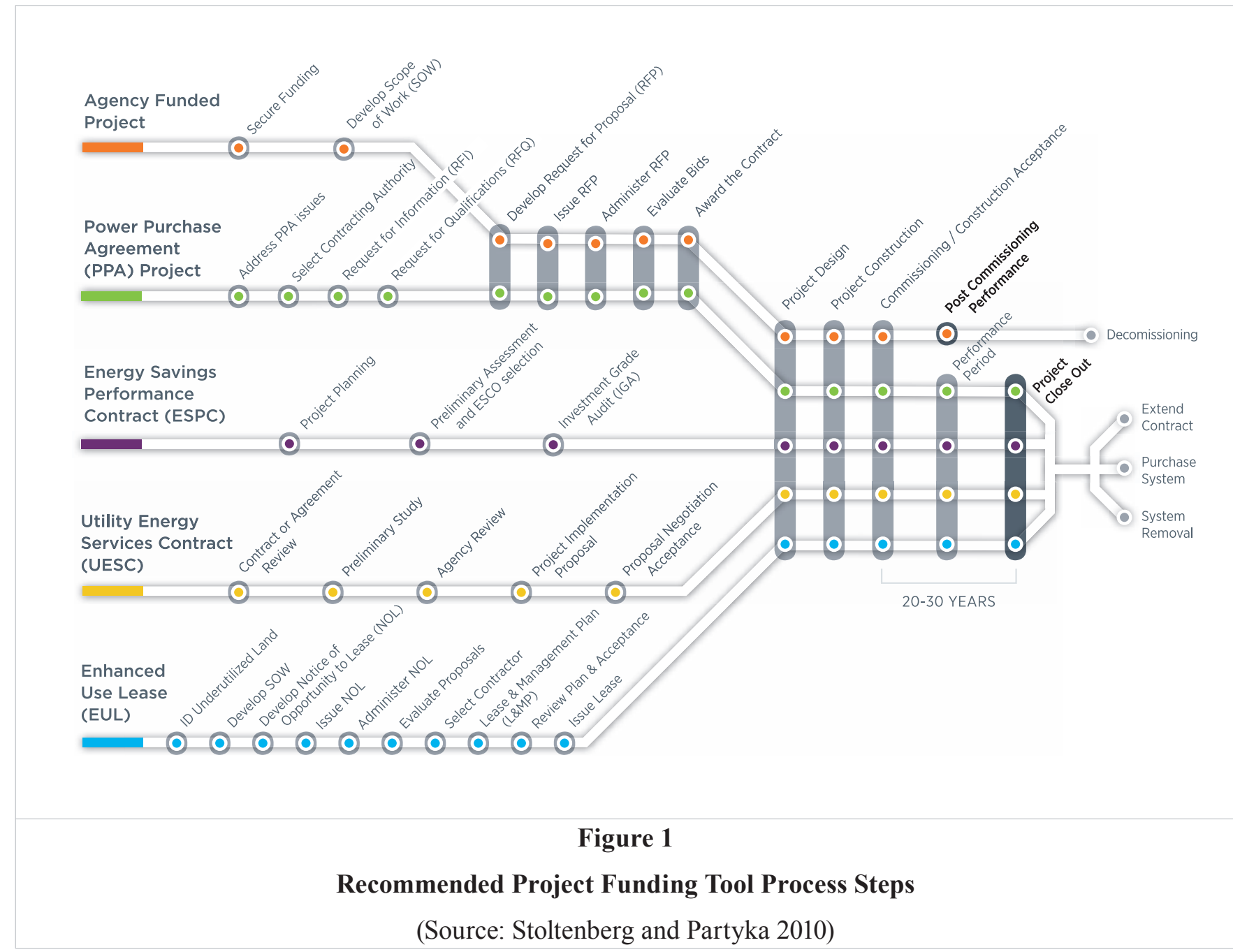

\section{Summary}

In addition to government appropriations, federal agencies have multiple solar project funding options. Some of the more common types of funding mechanisms have been described above. One of the first steps in selecting any funding tool or financing mechanism is to define the conditions and goals of the project. From there, the agency can evaluate which tool will provide the greatest value to the government and the taxpayer. The list provided in this document is intended to give agencies a starting place for considerations and options available to implement projects.

The rules of thumb given in each funding tool section can help determine which tool should be considered for specific projects. It is recommended that project decision-makers develop a background understanding of funding tools that meet rule-of-thumb criteria and then seek advice from FEMP federal financing specialists and other experts to aid in the selection of a funding tool. 


\section{The Solar Procurement Process for Federal Agencies}

For a more thorough examination of funding tools and the procurement process, see:

- Procuring Solar Energy: A Guide for Federal Facility Decision Makers (www1.eere.energy.gov/solar/federal guide/) This guide defines a two-part process for procuring solar energy. In Part I the guide outlines the planning process in five steps, which culminates with the selection of a funding tool. Part II focuses on implementing the selection.

- Solar Photovoltaic Financing: Deployment by Federal Government Agencies (www.nrel.gov/docs/fy09osti/46397.pdf) This in-depth presentation of solar project financing for federal agencies includes a more detailed discussion of the funding tools presented here.

- Slides and a transcript of a presentation based on Procuring Solar Energy www 1.eere.energy.gov/femp/pdfs/ns/solarfedguide presentation.pdf and http://www1.eere.energy.gov/femp/pdfs/ns/solarfedguide transcript.pdf

- The Department of Energy's Federal Energy Management Program (FEMP) website www.eere.energy.gov/femp/

- FEMP trainings http://apps1.eere.energy.gov/femp/training/

\section{Contact Information}

For more information on the solar energy procurement process, contact Blaise Stoltenberg at the National Renewable Energy Laboratory

(blaise.stoltenberg@nrel.gov).

\section{Sources}

DOE EERE (2010). Financing and Contracting Decisions for Solar Projects. Department of Energy, Office of Energy Efficiency and Renewable Energy website. wwwl.eere.energy.gov/solar/federal_guide/financing.html. Accessed September 13, 2011.

\section{Acknowledgments}

The author would like to thank co-author Bethany Speer of NREL and the following reviewers for providing their expert insights to inform this analysis: Karen Butterfield, Sun Power; Scott Province, Sun Edison; David McAndrew and Tracy Logan, DOE FEMP; Kyle Rudzinski, DOE SunShot; and Deb Beattie, Jeff Bedard, Michael Callahan, Karlynn Cory, Scott Gossett, David Kline, Dustin Knutson, Chandra Shah, and Karen Thomas, NREL. Also, thanks are in order for a couple of NREL experts who provided guidance to and assistance with the factsheet: John Barnett and Doug Dahle.

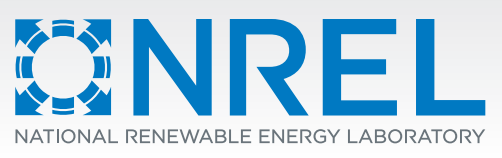

Analysis at NREL aims to increase

the understanding of the

current and future interactions

and roles of energy policies,

markets, resources, technologies,

environmental impacts, and

infrastructure. These analyses

are used to inform decisions as

energy-efficient and renewable

energy technologies advance

from concept to commercial

application.

National Renewable
Energy Laboratory
15013 Denver West Parkway
Golden, Colorado 80401
303-275-3000 www.nrel.gov

NREL is a national laboratory of the U.S. Department of Energy, Office of Energy Efficiency and Renewable Energy, operated by the Alliance for Sustainable Energy, LLC.

NREL/BR-6A20-53322・ March 2012 